Article

\title{
How to Comply with the Paris Agreement Temperature Goal: Global Carbon Pricing According to Carbon Budgets
}

\author{
Martin Zapf ${ }^{1, *(\mathbb{D}, \text { Hermann Pengg }}{ }^{2}$ and Christian Weindl ${ }^{1}$ \\ 1 Coburg University of Applied Sciences and Arts, Institute of High Voltage Technology, Energy System \& \\ Asset Diagnostics (IHEA), 96450 Coburg, Germany \\ 2 AUDI AG, 85045 Ingolstadt, Germany \\ * Correspondence: martin.zapf@hs-coburg.de
}

Received: 6 June 2019; Accepted: 30 July 2019; Published: 2 August 2019

check for updates

\begin{abstract}
Avoiding irreversible climate change as effectively as possible is one of the most pressing challenges of society. Carbon pricing that is uniformly valid on a global and cross-sectoral basis represents a cost-efficient policy tool to meet this challenge. Carbon pricing allows external costs to be allocated or internalized on a polluter-pays principle. It is shown that a global emissions cap-and-trade system is the most suitable market-based instrument for reducing global emissions levels, in line with the temperature goal set by the Paris Agreement. A proposal for its design is presented in this paper. This instrument encourages worldwide measures, with the lowest marginal abatement cost, according to a pre-defined reduction path. Thereby, it ensures compliance with a specified remaining carbon budget to meet a certain temperature limit in a cost-efficient manner. Possible reduction paths are presented in this paper. Weaknesses in the design of existing emissions trading systems (ETS), such as the EU ETS, are identified and avoided in the proposed instrument. The framework solves several problems of today's climate change policies, like the free rider problem, carbon leakage, rebound effects or the green paradox. The introduction of a global uniform carbon pricing instrument and its concrete design should be the subject of policy, especially at the United Nations climate change conferences, as soon as possible in order to allow for rapid implementation. If a global ETS with a uniform carbon price could be introduced, additional governmental regulations with regard to carbon emissions would become obsolete.
\end{abstract}

Keywords: Carbon pricing; carbon law; remaining carbon budget; reduction path; policy framework; emissions trading; Pigouvian tax; global cap-and-trade system across all sectors

\section{Introduction}

Avoiding irreversible climate change as effectively as possible is one of the most pressing challenges of society. A landmark international agreement to combat climate change was reached at the United Nations climate change conference in Paris. The Paris Agreement aims to keep the global temperature rise well below $2{ }^{\circ} \mathrm{C}$, above pre-industrial levels, and to pursue efforts to limit it to $1.5^{\circ} \mathrm{C}$ [1].

In this work, the status quo concerning anthropogenic greenhouse gas (GHG) emissions and findings concerning the remaining carbon budgets that refer to a certain temperature limit are shown. Reduction paths are set out, with the objective of meeting carbon budgets between 2020 and 2050. Based on a literature review, the state intervention possibilities for combating climate change and design possibilities of an emissions trading system are presented (cf. Sections 1-5).

The main aim of this paper is to derive a political instrument and its design, based on findings from the literature review, which will ensure the reduction of global emissions levels as cost-effectively 
as possible, in line with the temperature targets set by the Paris Agreement (cf. Section 6). Contrary to many other publications, which focus on different political instruments, carbon taxes or international carbon price floor arrangements, this paper shows that a global emissions trading system is the most suitable way to comply with carbon budgets that refer to a certain temperature limit. The basic idea of this system is that the worldwide annual emissions level is limited by certificates that allow for the emission of a certain amount of GHG. If the costs of abatement options are less than the purchase of the certificates, they will be implemented. This ensures the most cost-effective avoidance of GHG emissions, according to a pre-defined reduction pathway. Objections, from other publications, to the implementation of a global cap-and-trade system lead to divergent political recommendations, and these objections are investigated and refuted.

The challenge that climate change poses can only be solved with global cooperation. Requirements for international trade through a coalition of the willing can provide the necessary incentive to introduce and participate in the proposed global instrument. In addition, support payments, e.g., for developing countries, based on the revenues of carbon pricing, can serve as an incentive to participate in a global system.

\section{Status Quo Concerning GHG Emissions}

Decades of intensive and interdisciplinary research have shown that it is extremely likely that anthropogenic greenhouse gas (GHG) emissions are the cause of climate change [2,3]. Figure 1 shows the evolution over time of the contributions of man-made GHG emissions since 1970. The following polluters contributed to GHG emissions in 2010:

- $\mathrm{CO}_{2}$ from fossil fuel and industrial processes, with $65 \%$;

- Methane, with $16 \%$, and nitrous oxide, with $6 \%$, e.g., from agriculture;

- Reduction of $\mathrm{CO}_{2}$ sinks, with $11 \%$, e.g., through deforestation or the destruction of forests.

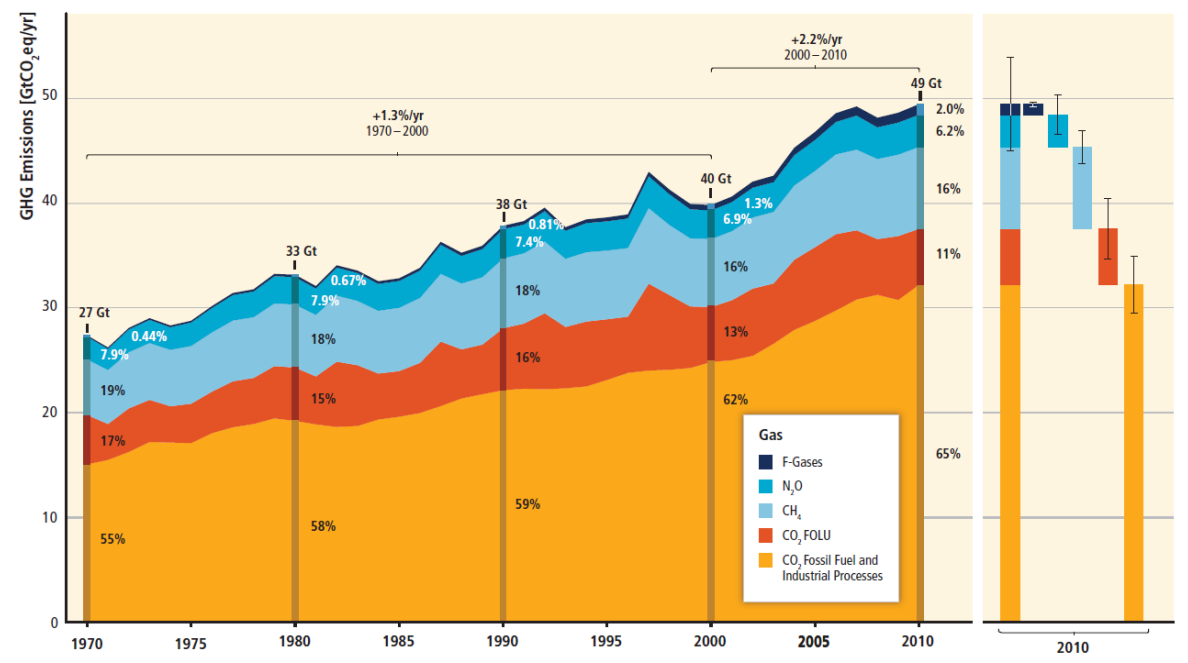

Figure 1. Total annual anthropogenic greenhouse gas (GHG) emissions $\left(\mathrm{GtCO}_{2 \mathrm{eq}} / \mathrm{yr}\right)$ by groups of gases from 1970-2010: $\mathrm{CO}_{2}$ from fossil fuel combustion and industrial processes; $\mathrm{CO}_{2}$ from forestry and other land use (FOLU); methane $\left(\mathrm{CH}_{4}\right)$; nitrous oxide $\left(\mathrm{N}_{2} \mathrm{O}\right)$; fluorinated gases covered under the Kyoto Protocol (F-gases). On the right side of the figure, the GHG emissions in 2010 are shown, again broken down into the aforementioned components, with the associated uncertainties $(90 \%$ confidence interval) indicated by the error bars. Global $\mathrm{CO}_{2}$ emissions from fossil fuel combustion are known to have an uncertainty within $8 \% . \mathrm{CO}_{2}$ emissions from FOLU have very large uncertainties, to the order of $\pm 50 \%$. The uncertainty for the global emissions of $\mathrm{CH}_{4}, \mathrm{~N}_{2} \mathrm{O}$ and F-gases has been estimated at $20 \%$, $60 \%$ and $20 \%$, respectively. Emissions are converted into $\mathrm{CO}_{2}$-equivalents, based on the 100-year global warming potential $\left(\mathrm{GWP}_{100}\right)$ from the IPCC Second Assessment Report (AR2). Using the GWP 100 values from the AR5, global GHG emissions totals would be slightly higher (52 $\mathrm{GtCO}_{2 \mathrm{eq}} / \mathrm{yr}$ ), and non- $\mathrm{CO}_{2}$ emissions shares would be $20 \%$ for $\mathrm{CH}_{4}, 5.0 \%$ for $\mathrm{N}_{2} \mathrm{O}$ and $2.2 \%$ for F-gases [4]. 
In 2015, the annual $\mathrm{CO}_{2}$ emissions from fossil fuel combustion reached $32.3 \mathrm{GtCO}_{2}$ worldwide. Coal and oil together have contributed about $80 \%$ steadily to the annual $\mathrm{CO}_{2}$ emissions from fossil fuel combustion since 1970. Coal's contribution has increased since 1970 and overtook oil between 2000 and 2005. The share of natural gas has risen from about $15 \%$ to about $20 \%$ [5].

In a recent IPCC publication, the so-called remaining carbon budgets has been calculated, which would allow the global mean surface temperature (GMST) increase, relative to pre-industrial levels (reference period, $1850-1900$ ), to be limited to less than $1.5^{\circ} \mathrm{C}$ in order to prevent irreversible changes to the global climate [2]. To remain below the $1.5^{\circ} \mathrm{C}$ limit with a relatively high probability, it is stated: "Reaching and sustaining net zero global anthropogenic $\mathrm{CO}_{2}$ emissions and declining net non- $\mathrm{CO}_{2}$ radiative forcing would halt anthropogenic global warming on multi-decadal time scales (high confidence)" [2]. It is further recommended, according to model pathways with no or a limited overshoot of $1.5^{\circ} \mathrm{C}$, to reach the net zero anthropogenic $\mathrm{CO}_{2}$ emissions by around 2050. These pathways also imply a reduction of most of the cooling aerosols, a desired outcome, but unfortunately with an amplifying impact on future warming that is undesirable. In addition to the reduction of anthropogenic $\mathrm{CO}_{2}$ emissions to around zero till 2050, carbon dioxide removal (CDR) measures are expected to be required, especially afforestation and bioenergy, with carbon capture and storage (BECCS). Non- $\mathrm{CO}_{2}$ GHG emissions, mainly methane and nitrous oxide, also have to be reduced substantially by 2050 . A $1.5^{\circ} \mathrm{C}$ pathway, with no or a limited overshoot, is defined as a temperature increase that remains below $1.5^{\circ} \mathrm{C}$ until 2100 or does not rise significantly above that temperature (less than $0.1^{\circ} \mathrm{C}$ ) [2].

"Mitigation requirements can be quantified using carbon budget approaches that relate cumulative $\mathrm{CO}_{2}$ emissions to global mean temperature increase. Robust physical understanding underpins this relationship, but uncertainties become increasingly relevant as a specific temperature limit is approached" [6]. The remaining carbon budget is defined as the "estimated cumulative net global anthropogenic $\mathrm{CO}_{2}$ emissions from a given start date to the time that anthropogenic $\mathrm{CO}_{2}$ emissions reach net zero that would result, at some probability, in limiting global warming to a given level, accounting for the impact of other anthropogenic emissions" [2]. Starting in 2018, the remaining carbon budget is specified to be about $420 \mathrm{GtCO}_{2}$, for a two-thirds chance of limiting warming to $1.5^{\circ} \mathrm{C}$, and about $580 \mathrm{GtCO}_{2}$ for an even chance (with medium confidence because of uncertainties, see below). The corresponding remaining carbon budget for limiting warming to $2{ }^{\circ} \mathrm{C}$ is $1170 \mathrm{GtCO}_{2}$ (two-thirds chance) and $1500 \mathrm{GtCO}_{2}$ (even chance) [7].

This implies that the $1.5^{\circ} \mathrm{C}$ goal will definitely not be reached under the current nationally determined contributions (NDCs), as stated under the Paris Agreement, assuming that a sudden reduction to zero from 2030 onward is technologically and economically impossible. The successful implementation of NDCs under the Paris Agreement would imply a total of $400-560 \mathrm{GtCO}_{2}$ emissions over the 2018-2030 period (considering both conditional and unconditional NDCs) [7].

There are, however, substantial uncertainties regarding the estimated remaining carbon budgets. "For the budget, applicable to the mid-century, the main uncertainties relate to the transient climate response to cumulative carbon emissions (TCRE), non- $\mathrm{CO}_{2}$ emissions, radiative forcing and response. For 2100, uncertain Earth system feedbacks such as permafrost thawing would further reduce the available budget. The remaining budget is also conditional upon the choice of baseline, which is affected by uncertainties in both historical emissions, and in deriving the estimate of globally averaged human-induced warming" [7]. These uncertainties lead to a medium confidence of currently detecting the remaining carbon budgets, with possible deviations upwards and downwards.

\section{Reduction Paths: Carbon Law Adapted to a $1.5^{\circ} \mathrm{C}$ Target with an Exponential or Logistic Decrease}

In this paper, possible reduction paths that could limit global warming to $1.5^{\circ} \mathrm{C}$, with no or a limited overshoot, for a two-thirds chance (or even chance) are investigated. The corresponding ambitious remaining carbon budgets were chosen to avoid the possibility of missing even the $2{ }^{\circ} \mathrm{C}$ 
pathway due to the prevailing uncertainties and lagging action. This possibility must be avoided for the following reasons:

- The severity of damage increases nonlinearly, with a GMST increase of over $2{ }^{\circ} \mathrm{C}$ [8]. Acting too late or not ambitiously enough could lead to nonlinear self-reinforcing and irreversible processes (tipping points, cf. Section 6.6) that would amplify warming, despite costly efforts;

- The reliance on net negative emissions to return warming to a specific temperature limit should be minimized, as there is still a lack of understanding of how the carbon cycle responds to net negative emissions. Thus, the effectiveness of negative emissions technologies to decrease the temperature after a peak is uncertain [7];

- Furthermore, " $[$... ] delaying GHG emissions reductions over the coming years also leads to economic and institutional lock-in into carbon-intensive infrastructure, that is, the continued investment in and use of carbon-intensive technologies that are difficult or costly to phase-out, once deployed" [7].

Given these findings, it seems rational to choose ambitious carbon budgets to maximize the success probability and at the same time minimize the overall transformation costs, despite the uncertainties involved in the assessment of the carbon budgets. Determining the specific size of the necessary carbon budget is, however, not the goal of this paper. It should be determined in political discussions on the basis of current scientific findings. The methods proposed in this paper can be applied, independently of the size of the remaining carbon budget. The goal is to present an instrument that ensures global carbon emissions stay within a chosen carbon budget, eventually minimizing costs along the transformation pathway.

As stated in [9], the necessary reduction regarding greenhouse gas $\mathrm{CO}_{2}$ can be described with a simple power law, named the carbon law, which states that global anthropogenic $\mathrm{CO}_{2}$ emissions must be at least halved each decade between 2020 and 2050. The scenario for the carbon law, shown in [9], is based on a remaining carbon budget of $700 \mathrm{GtCO}_{2}$ between 2017 and 2100 . The heuristics of the carbon law are simple but not oversimplifying, and they condense the scientific findings on climate change into a clearly measurable quantity. Based on the previously presented current carbon budgets, according to the IPCC Special Report $1.5^{\circ} \mathrm{C}$, the concept has been updated and modified in [10]. Assuming that the associated remaining budget is being depleted by current emissions of $42 \pm 3 \mathrm{GtCO}_{2}$ per year (cf. [2]), the remaining budget from 2020, for a $66 \%$ (or $50 \%$ ) chance of limiting warming to $1.5{ }^{\circ} \mathrm{C}$, is approximately $340\left(500 \mathrm{GtCO}_{2}\right)$. As a modification, the use of the first derivative of a logistic function is proposed as a possible alternative to an exponential function in describing the reduction pathway. The corresponding reduction paths are shown in Figure 2.

Blue lines represent budgets of $340 \mathrm{GtCO}_{2}$, until 2050, and black lines represent budgets of 500 $\mathrm{GtCO}_{2}$. The dotted line represents a path for a budget of $500 \mathrm{GtCO}_{2}$, if the exponential reduction starts in 2025 instead of 2021. The dashed lines represent reductions along exponential functions, and the solid lines represent reductions along logistic functions. In order to meet the $1.5{ }^{\circ} \mathrm{C}$ target, with no or a limited overshoot and an even or two-thirds chance, the annual global anthropogenic $\mathrm{CO}_{2}$ emissions must therefore be reduced from approx. $40 \mathrm{GtCO}_{2} / \mathrm{yr}$. in 2020 to the following values:

- $\quad 11-22 \mathrm{GtCO} / \mathrm{yr}$. by 2030 , i.e., a reduction of $46-72 \%$, compared to 2020 ;

- $1-9 \mathrm{GtCO} 2 / \mathrm{yr}$. by 2040 , i.e., a reduction of $77-97 \%$, compared to 2020 ;

- $\quad 0-4 \mathrm{GtCO} 2 / \mathrm{yr}$. by 2050, i.e., a reduction of $89-100 \%$, compared to 2020.

If the abovementioned exponential reduction paths, shown in Figure 2 for budgets of 340 and 500 $\mathrm{GtCO}_{2}$ until 2050, extrapolated to 2100, an additional 13 and $55 \mathrm{GtCO}_{2}$ will be emitted cumulatively between 2050 and 2100 (0-7 GtCO 2 for a logistic decrease). These emissions would have to be counterbalanced by CDR measures. The results are comparable with pathways that limit global warming to $1.5^{\circ} \mathrm{C}$, with no or a limited overshoot, that have been presented in [7]. In addition, an ambitious reduction of non- $\mathrm{CO}_{2}$ greenhouse gases, such as methane, nitrous oxide and black carbon, needs to be pursued [7]. 


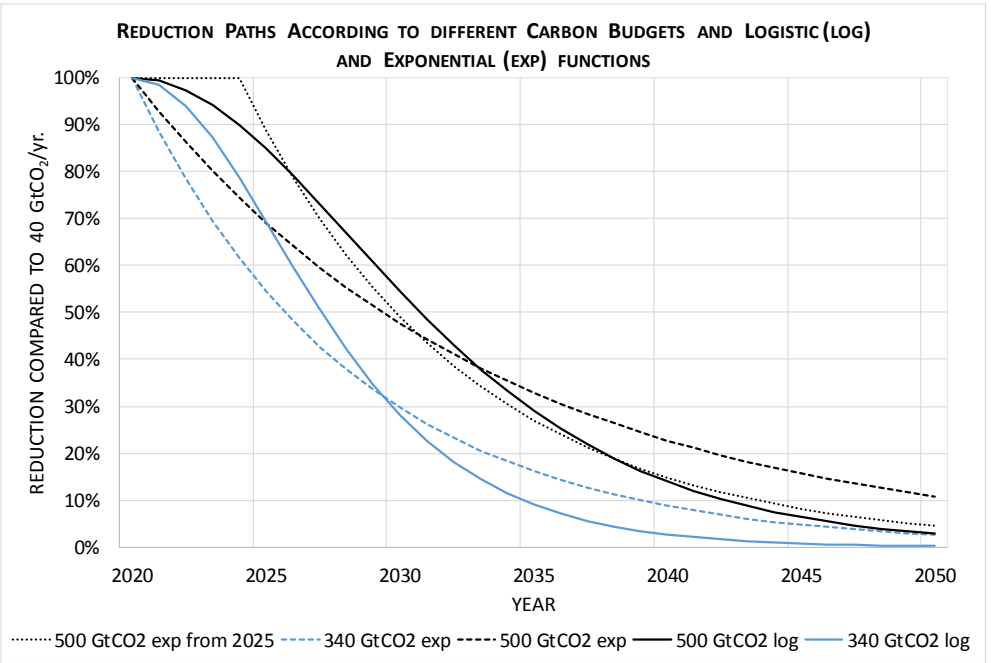

Figure 2. $\mathrm{CO}_{2}$ reduction pathways between 2020 and 2050, limiting the $\mathrm{CO}_{2}$ budget to 340 (500) $\mathrm{GtCO}_{2}$ until 2050 along exponential and logistic curves [10].

The introduction of a policy framework generally appears to be an efficient method to reduce environmental impacts, if the targets are correctly defined. The proposed reduction paths, shown above, are only exemplary, and other curves could also be considered, e.g., linear or polynomial functions. However, a reduction along an exponential function or a logistic function seems to be an assumption that is consistent with observations. Environmental impacts have been reduced along exponential or logistic functions in the following examples within two decades:

- The annual consumption of ozone depleting substances (ODS) was reduced by more than $99 \%$ from 1986 (>1.3 Mt/year) to 2016, and the reduction can be approximately described by a logistic function [11,12];

- Sulphur dioxide emissions in Europe were reduced by 74\% between 1990 and 2011 approximately exponentially [13], and sulphur dioxide, nitrogen dioxide and mercury emissions were reduced in the USA roughly along logistic functions [14].

The basis for the reduction of GHG emissions is the substitution of GHG-intensive by less GHG-intensive technologies. Hence, another argument relies on a large database of technology substitution processes that can often be described by logistic functions (cf. [15]).

The proposed reduction paths could in principle be validated by integrated assessment models (IAMs) to ensure low-cost pathways that achieve, physical climate targets that are socially agreed upon. However, such costs are highly uncertain [16].

\section{Internalization of the External Effects of Anthropogenic GHG Emissions: Possible Policy Frameworks}

How should the policy framework be devised in order to achieve the enormous GHG savings, compared with current global emissions levels, which are necessary to avoid irreversible climate change? It can be assumed that the most suitable framework would need to make sure that the necessary reduction targets are met, while simultaneously reducing economic damage and social repercussions to a minimum.

Perfect competition only leads to efficient market results, as long as there are no external effects [17]. External effects exist if the actions of one individual (or company) directly influence the benefits or costs of another individual (or company). As this influence is not reflected in market prices, its effects are named external [18]. A welfare-optimal allocation of resources can only be achieved if external effects are internalized. Negative externalities represent external costs. The pollution of the environment by individuals (or companies) is a form of negative externality, creating external costs for other individuals 
(or companies). In case of GHG emissions, the influence of externalities extends not only beyond the boundary of the responsible polluting individual (or company), but also beyond the borders of the country of the responsible individuals (or companies) and beyond the present time into the future. Externalities lead to market failure, because market prices do not accurately reflect the true costs and benefits. These distortions of the market can be eliminated by internalizing the external costs, e.g., by charging the external costs equally to the polluter. In case an individual (or company) contributes a benefit to society, e.g., by measures that generate $\mathrm{CO}_{2}$ sinks, this would represent an external benefit-consumers would have to pay the responsible person a certain amount as compensation corresponding to the benefit [19].

External effects are currently not or only insufficiently reflected in prices, hence market forces cannot act efficiently in the direction of welfare optimization. For environmental problems involving many actors, negative externalities can no longer be internalized through direct negotiations (Coase theorem), and state intervention is therefore required to correct the market failure [18]. A state can remedy the internalization of external costs in the following ways:

1. Legal requirements (command and control approach), e.g., statutory emissions thresholds;

2. Pigouvian tax and subsidies;

3. Emissions trading.

For emissions that affect the environment on a global scale, such as GHG emissions, imposing legal requirements do not lead to cost-efficient reductions. This is justified as follows $[18,20,21]$ :

- Legal requirements, e.g., a uniform emissions threshold for all polluters, lead to a lack of options for polluters to implement measures at the lowest marginal abatement costs;

- A design of the legal requirements, in accordance with the lowest marginal abatement costs, would require the state to be aware of the marginal abatement costs of each polluter. The state would therefore be dependent on receiving correct information from all polluters, the monitoring effort would be considerable, and there would be uncertainties in the accuracy of the information;

- Additionally, the regulator would have to adjust the requirements over time so that the private benefits from investing in the new technology equal the social benefits-a task that seems very difficult to achieve, considering the complexity of the systems involved and the uncertainties associated with the necessary estimates;

- The incentive to invest in new technologies, as well as in the most cost-effective ones, is lower for the legal requirements than for the market-based instruments.

Given these arguments, it can be concluded that market-based instruments-Pigouvian tax and emissions trading - are to be preferred for the cost-efficient reduction of globally effective externalities, like it is the case for GHG emissions. The greater the differences in the cost of abating pollution across sources, the greater the likely cost savings from a market-based system, relative to the legal requirements $[22,23]$.

\section{Global Carbon Pricing}

Climate change can only be limited through cooperation and the correct framework conditions. As stated in [24], individual responsibility and Paris' pledge-and-review approach will fail as long as they are based on individual commitments. Carbon pricing is the best instrument for a common commitment. "There is broad acceptance among analysts, governments and businesses that carbon pricing is (by far) the most efficient instrument for reducing $\mathrm{CO}_{2}$ emissions (see http://www.carbonpricingleadership. org/carbon-pricing-panel)" [24]. So far, however, there is no binding global agreement concerning carbon pricing. Currently, the carbon price systems that exist focus on the regional (e.g., European), national (e.g., Chinese) or sub-national (e.g., Californian) levels. Cap-and-trade schemes are frequently used for carbon pricing [25]. Some efforts already exist to link the different emissions trading systems (ETS) with each other $[25,26]$. Current information on carbon pricing initiatives can be found at 
https://carbonpricingdashboard.worldbank.org and https:/icapcarbonaction.com. In 2020, almost 20\% of all GHG emissions worldwide, which is approximately $11 \mathrm{GtCO}_{2 \mathrm{eq}}$, will be covered by carbon pricing initiatives [27]. Figure 3 shows the status of the initiatives in 2018. The prices vary significantly, from less than $1 \mathrm{USD} / \mathrm{tCO} 2 \mathrm{eq}$ to a maximum of $139 \mathrm{USD} / \mathrm{tCO}_{2} \mathrm{eq}$ [27].

Considering the above, both a Pigouvian tax and emissions trading are appropriate for the design of carbon pricing schemes. In the following, it will first be justified why quantity control (emissions trading) is an instrument preferable to price control (Pigouvian tax) in the case of climate protection according to the temperature goal of the Paris Agreement. It will also be argued that a global scheme is more advantageous than national and sectoral carbon pricing schemes. Finally, the basic properties of an efficient global cap-and-trade system are proposed.

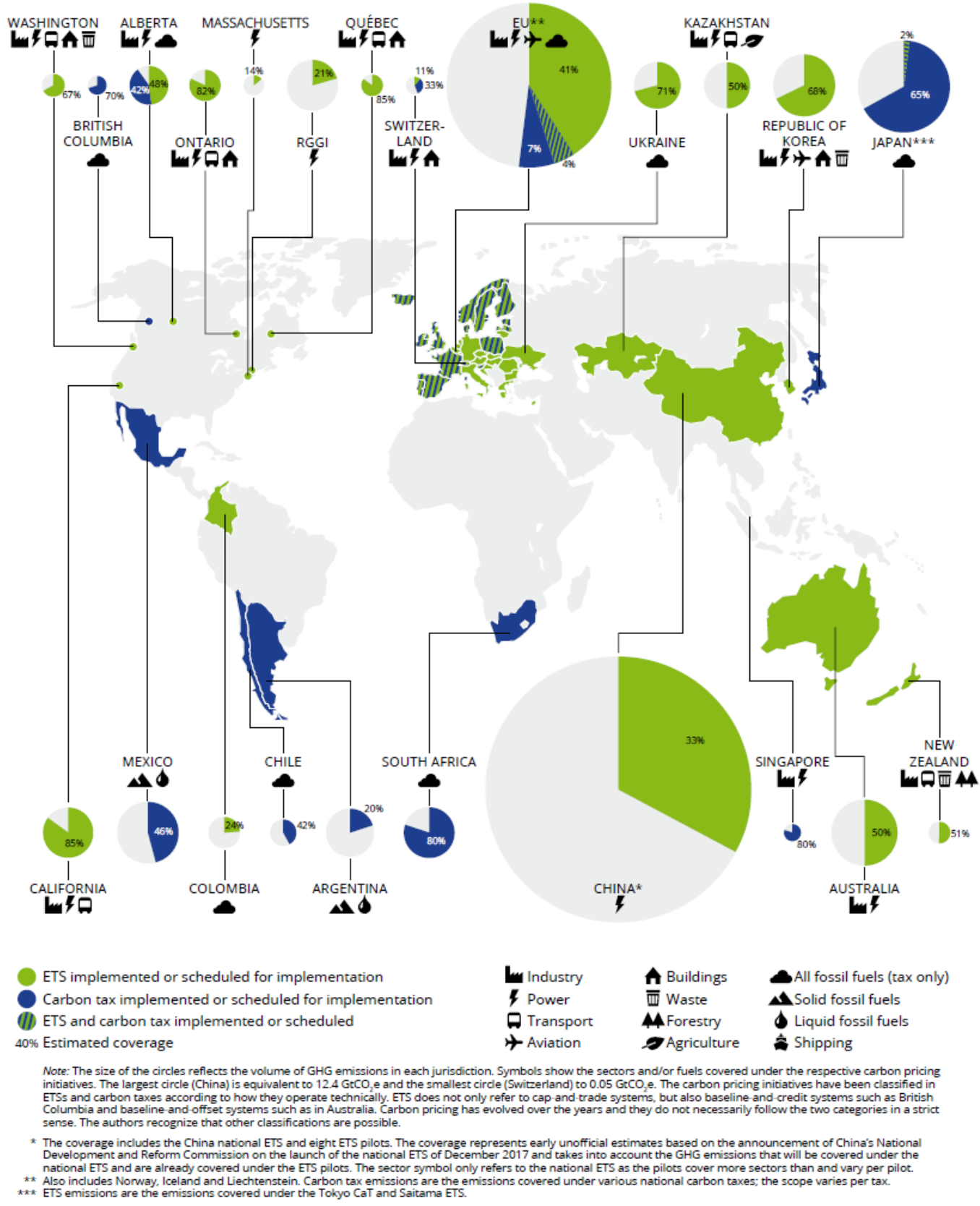

Figure 3. Carbon pricing initiatives, implemented or scheduled for implementation, with sectoral coverage and GHG emissions covered [27]. 


\subsection{Quantity Control (Emissions Trading) vs. Price Control (Pigouvian Tax)}

It should be noted, first, that it is not economically efficient to abruptly reduce the current emissions level to zero. The reason for this is that the abatement costs would be very high in this case.

The optimal emissions level is given under the following conditions [18]:

- The sum of the abatement and damage costs is minimal; in other words:

- The marginal damage is equal to the marginal abatement costs.

A Pigouvian tax represents a simulated price for the environment concerning the consumption or use of environmental goods, which leads microeconomic decision-makers to take the costs of environmental consumption into account in their decisions. It has been named after the British economist Arthur Pigou, who proposed this type of state intervention, as early as 1920, in his work, "The Economics of Welfare" [18]. In the case of the Pigouvian tax, the planner in charge must determine the optimum tax rate for a given year and predict the optimum tax rate for future years. For that, it is necessary to know the marginal damage over time. The social cost of carbon (SCC) represents the cost of all present and future damages, caused by an additional ton of carbon dioxide emissions or its equivalent, discounted to the year of emissions [28,29]. "The SCC is normally computed with an Integrated Assessment Model (IAM), which is a model combining descriptions of the economy and of the climate system" [30]. Commonly used IAMs for the computation of the SCC are the Dynamic Integrated Climate-Economy (DICE) model, the Policy Analysis of the Greenhouse Effect (PAGE) model, and the Climate Framework for Uncertainty, Negotiation and Distribution (FUND) model (cf. [31-33]). Even though it is tried by IAMs, however, the SCC can neither be precisely determined nor predicted (cf. $[16,34]$ ) due to the complexity of the systems involved and the resulting problems in modeling those systems, the incompleteness of the available information, the limited resources to calculate these estimates and the uncertainties concerning the given information. Similar fundamental problems arise in the process of determining or predicting the marginal abatement costs.

When the marginal costs are uncertain, it has been proved that quantity control (emissions trading) is preferable to price control (Pigouvian tax), if the increase in the marginal damage costs is higher than the increase in the marginal abatement costs or in other words if the benefits are highly nonlinear, while the costs are close to linear (relative slopes rule). In the reverse case, the Pigouvian tax is to be preferred accordingly. Depending on the case, an identical percentage error in the emissions quantity or in the emissions price leads to a higher welfare loss. This important result is drawn from an article by Martin Weitzman in 1974 (Weitzman's rule) [18,21,35,36]. This understanding would, in principle, allow a decision as to which of the two proposed methods should be applied in any given situation. Further, it should be noted that the presence of simultaneous and correlated benefit and cost uncertainty can reverse the price or quantity instrument superiority, according to the relative slopes rule [37].

As mentioned above, limiting warming to below $1.5^{\circ} \mathrm{C}$, with no or a limited overshoot and a certain probability, corresponds to keeping future cumulative global $\mathrm{CO}_{2}$ emissions within a certain limit, i.e., the carbon budget. The remaining carbon budget can be determined on a scientific basis, given a certain desired degree of climate change limitation. In order to meet this budget with an instrument cost-efficiently, it is not necessary to have exact knowledge of the future social cost of carbon.

Based on the statements that have been presented above, it is now possible to rule out a Pigouvian tax (price control) by the following arguments:

- Criterion for exclusion: A Pigouvian tax controls the price, not the quantity. Hence, it will not necessarily ensure that global $\mathrm{CO}_{2}$ emissions stay within a previously defined remaining carbon budget, which is a necessary condition for an instrument to be useful in limiting global warming to a specific temperature limit;

- Marginal abatement costs and marginal damage costs, and even the slope of them, cannot be calculated with sufficient accuracy. Hence, Weitzman's rule cannot be used to identify a case where a Pigouvian tax would eventually be more favorable than emissions trading; 
- Weitzman's rule tells us that there is likewise a chance that emissions trading is more favorable than a Pigouvian tax, even if the criterion for exclusion would not hold.

Further explanations and evidences of these arguments are listed in Section 6.6.

Compared to the Pigouvian tax, an emissions trading system (ETS), with a cap defined by an annual emissions budget, is more suitable for limiting $\mathrm{CO}_{2}$ quantities. Even under changing market conditions, emissions trading would ensure that the scientifically defined goal is achieved in any case [18]. This instrument also ensures, for example, that rebound effects do not lead to emissions increases. In a cap-and-trade system, the annual emissions are limited by an upper limit (cap), and the corresponding quantity is allocated or auctioned as individual emissions certificates. The quantity of permits is reduced annually on the basis of a reduction path to be implemented. It is permitted to trade the emissions certificates. Thus, emissions can be avoided where the lowest marginal abatement costs are generated. Due to the volume limitation, compliance with the prescribed emissions budget is guaranteed.

The reduction paths, shown in Figure 2, can provide a basis for calculating the annual emissions budget (cap) of a global ETS. Given a defined path, the number of auctioned emissions certificates has to be reduced accordingly. These reduction curves do not necessarily represent a cost-optimal path, in which the sum of abatement and damage costs is always minimal. However, as outlined above, it is improbable that such a perfectly cost-optimal path can be calculated at all. The best that can be accomplished under the given uncertainties is that overall abatement costs are minimized to the greatest possible extent, while ensuring global $\mathrm{CO}_{2}$ emissions remain within a certain carbon budget.

A further degree of freedom could allow for an even more cost-efficient reduction path: Certificates may be devalued, not only in the year of purchase, but also in later years, which is called banking. "Quantity-based regulation with banking allows regulated firms to shift obligations across time in response to periods of unexpectedly high or low marginal costs" [38]. This can be an effective way to exploit the uncertainty and irreversibility of investments [39]. It has proven to be very important to maximize trading profits. Quantity control without banking can lead to price spikes and collapses [22]. The design requirements and effects of banking are examined, among other places, in [38,40].

Furthermore, the efficiency can be increased by a hybrid system that combines price and quantity control [41-44]. Hybrid policies, e.g., cap-and-trade with a price ceiling, are more efficient than either price or quantity control by themselves. Besides an enhanced welfare outcome, a hybrid system improves the flexibility and credibility of a cap-and-trade system [42]. In principle, price ceilings aim to avoid exorbitant costs associated with price spikes. Therefore, additional permits will be available, if a specified trigger price is reached [45]. In this context, a hard price ceiling yields a lower net present value of the expected abatement costs than a soft price ceiling. A hard ceiling here means that an unlimited supply of additional permits will be available at the trigger price, whereas a soft ceiling means that the additional permits are limited [46]. "The former provides absolute price control, with some emissions flexibility, while the latter provides absolute emissions control, while allowing prices to fluctuate beyond the soft ceiling level" [45]. Thus, to comply with a carbon budget in a reliable way, only soft ceiling is applicable. However, there are serious concerns regarding a soft ceiling in combination with the grandfathering of permits. Eliminating the grandfathering would be beneficial to controlling prices [45].

Besides price ceilings, another design option for a hybrid system is a price floor or auction reserve price on emissions permits, as it is applied in, e.g., California's Cap-and-Trade System [22]. With an auction reserve price, permits are held until the reservation price is exceeded. Price floors aim to stimulate investments in emissions abatement technologies; otherwise, low prices provide an insufficient incentive [45,47].

If only the net present values of abatement costs are compared, without explicit consideration of damages or welfare, then taxes generally provide the lowest costs. However, a cap-and-trade system, with a combination of a price ceiling and price floor (called symmetric safety valve or price collar), 
banking and restricted borrowing can achieve abatement costs almost as low as a tax, but with a lower emissions variance than a tax [48].

\subsection{National vs. International and Sectoral vs. Cross-Sectoral Structuring}

A national design is unsuitable for carbon pricing due to the global interactions and international competition. A national structure would require exemptions for industry (like free allocation of emissions certificates) or carbon pricing for all imports and compensation of carbon pricing for all exports (border carbon adjustments $[49,50]$ ), which can involve complex life cycle analysis (LCA). Otherwise, companies and technologies affected by national carbon prices would be disadvantaged, and GHG emissions would be shifted to other countries (carbon leakage). It has been stated, in a large number of publications, that the climate change problem can only be solved globally $[18,24,51,52]$. Different carbon prices, in different countries and sectors, will lead to cost-inefficient pathways, e.g., due to technologies that become temporarily cost-effective in some countries and sectors, but eventually cost-ineffective again in a future emission-free target scenario. In particular, if an expensive infrastructure is involved in the introduction of new technologies, this could lead to significant stranded assets along the transformation pathway.

An equal carbon price should exist for all actors engaged in international trade. Accordingly, participation in global carbon pricing must be a pre-requisite for international trading. Trading with actors not involved in the international cap-and-trade system should only be possible if the corresponding carbon prices are included in the negotiation process, e.g., by border carbon adjustments. If a sufficient coalition of the willing can be found for such an international instrument, this would eventually generate incentives for other actors to participate in the global scheme (cf. [53]).

Carbon pricing should also be implemented across economic sectors to enable cost-inefficient pathways. This is not the case for the current EU ETS. $\mathrm{CO}_{2}$-intensive sectors, such as that of transport, are not yet included in trading. Only electricity generation is covered practically completely in the EU. The current global practice shows that it is possible to cover different sectors using an ETS. (cf. Figure 3). The number of actors affected by the current EU ETS is relatively small. For certain sectors, such as those of transport and heating, millions of actors would be involved. To deal with this problem, implementing an upstream system is a possible option [54,55]. Upstream means that the emissions can be allocated to a specific input, such as an energy source, through a fixed input-output ratio. Using this approach, complex emissions measurements for each emitter could be avoided. The system would not need to monitor millions of emitters, but a comparatively small number of companies that bring an input to the market that cause a certain amount of $\mathrm{CO}_{2}$, e.g., fossil fuels. An upstream system could cover all areas where fossil fuels are used (share of $\mathrm{CO}_{2}$ emissions from fossil fuels, cf. Figure 1). This is based on the fact that there is a well-known proportional relationship between the volumes of fossil fuels (such as coal, mineral oil products and natural gas) and the resulting $\mathrm{CO}_{2}$ emissions (emissions factor). In this case, an upstream system would combine minimal administrative and monitoring costs with a high accuracy. Considering, e.g., the transport sector, only the few fuel suppliers would have to be monitored, instead of the large number of fuel users [56]. The design of an upstream system can draw on existing ETS, such as the New Zealand ETS. A combined solution (mixed system) of a downstream and upstream emissions trading system is appropriate, if, on the one hand, no concrete input-output relationships can be established in some cases (downstream approach), and if, on the other hand, a high number of small emitters needs to be integrated into certain sectors, whose emissions can be traced back to certain inputs with an assignable input-output relationship, which originate from a few marketers (upstream approach). In the downstream approach, emissions are to be measured at the source.

\section{Derived Political Instrument-A Global Cap-and-Trade System across All Sectors}

According to the explanations given above, a global uniform and cross-sectoral ETS for $\mathrm{CO}_{2}$ appears to be the most cost-efficient instrument for accurately meeting given carbon budgets. The introduction 
of such a global uniform carbon pricing system and its concrete design should become the subject of policy, especially at the United Nations climate change conferences, as soon as possible in order to allow for rapid implementation. Such a system would allow the external costs of $\mathrm{CO}_{2}$ to be included in market prices, and this would be the same worldwide, which would solve the free rider problem [24]. Currently, there are already cross-sectoral emissions trading systems worldwide, as shown in Figure 3. The experience of these can be used for the conception of a uniform global ETS (cf. [22,57]). The derived political instrument based on the findings from the literature review in the previous sections, is summarized in Figure 4.

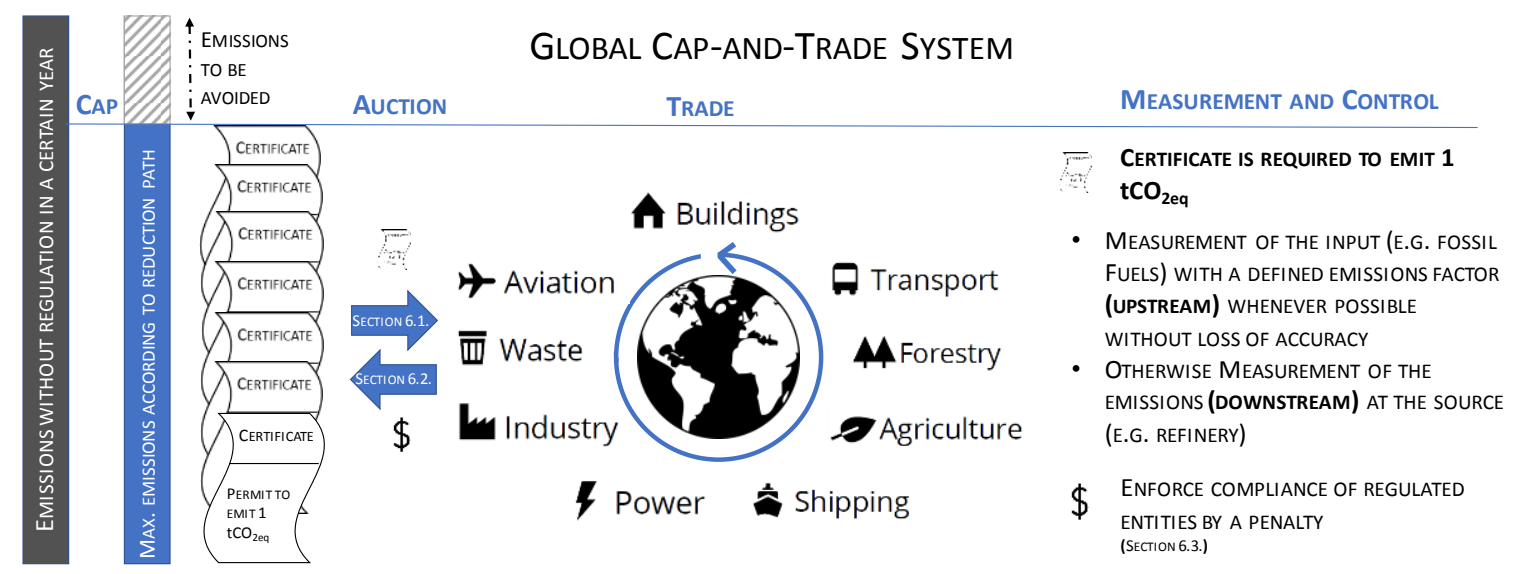

THE MAIN AMOUNT OF ANTHROPOGENIC $\mathrm{CO}_{2}$ IS REFERABLE TO THE COMBUSTION OF FOSSIL FUELS (APPROX. $32 \mathrm{GtCO}_{2}$ IN 2015) - MAINLY OIL, COAL AND NATURAL GAS - WHICH WOULD BE ASSESSED EQUALLY IN ANY SECTOR AND COUNTRY WITH A GLOBAL SYSTEM

Figure 4. Derived political instrument-A global cap-and-trade system across all sectors.

For the global ETS, banking and a hybrid design is proposed. The latter is explained in the following and is shown in Figure 5. The illustration is simplified and represents a linear reduction path. As explained in Section 3, an exponential or logistic reduction path is probably more suitable. The presented paths for achieving $1.5^{\circ} \mathrm{C}$ could provide an assessment basis for the baseline reduction path. In the hybrid system, permits are auctioned (cf. Section 6.3) according to a baseline reduction path to limit the temperature increase to $1.5^{\circ} \mathrm{C}$ with a certain probability. As soon as a price floor is reached, permits are transferred to the reserve, and as far as a price ceiling is triggered, permits from the reserve are, additionally, auctioned. The price limits vary over the time.

The permits that can be auctioned annually out of the reserve are limited, according to the formula provided in the figure. The reserve has to be designed in such a way as to ensure that, at any time, the globally agreed temperature target can be met. With the proposed design, a more cost-effective reduction path can be achieved, compared to the baseline reduction path. If new scientific evidence leads to the need to adjust the carbon budget over time, this can be achieved, first, by adapting the reserve. Only if the temperature target can no longer be achieved without the reserve will the baseline path need to be adjusted.

In sum, a global cap-and-trade system allows an ecological goal, which is politically agreed upon, to be achieved under uncertain boundary conditions in a cost-efficient way. The most efficient reduction path that can be predicted have to be predetermined in advance. This path can be further optimized by the design of the ETS, as it is a hybrid system that also allows for the possibility of banking. If the proposed system is implemented globally, market prices would include information on the resulting GHG emissions. Thus, an additional assessment and product differentiation, according to the emissions level, for example, according to complex life cycle analyses, would not be necessary. This represents a significant simplification for the end user, compared to the current situation.

The following sections outline the individual aspects of the proposed policy instrument. In addition, objections to the implementation of a global cap-and trade system are stated and refuted. 


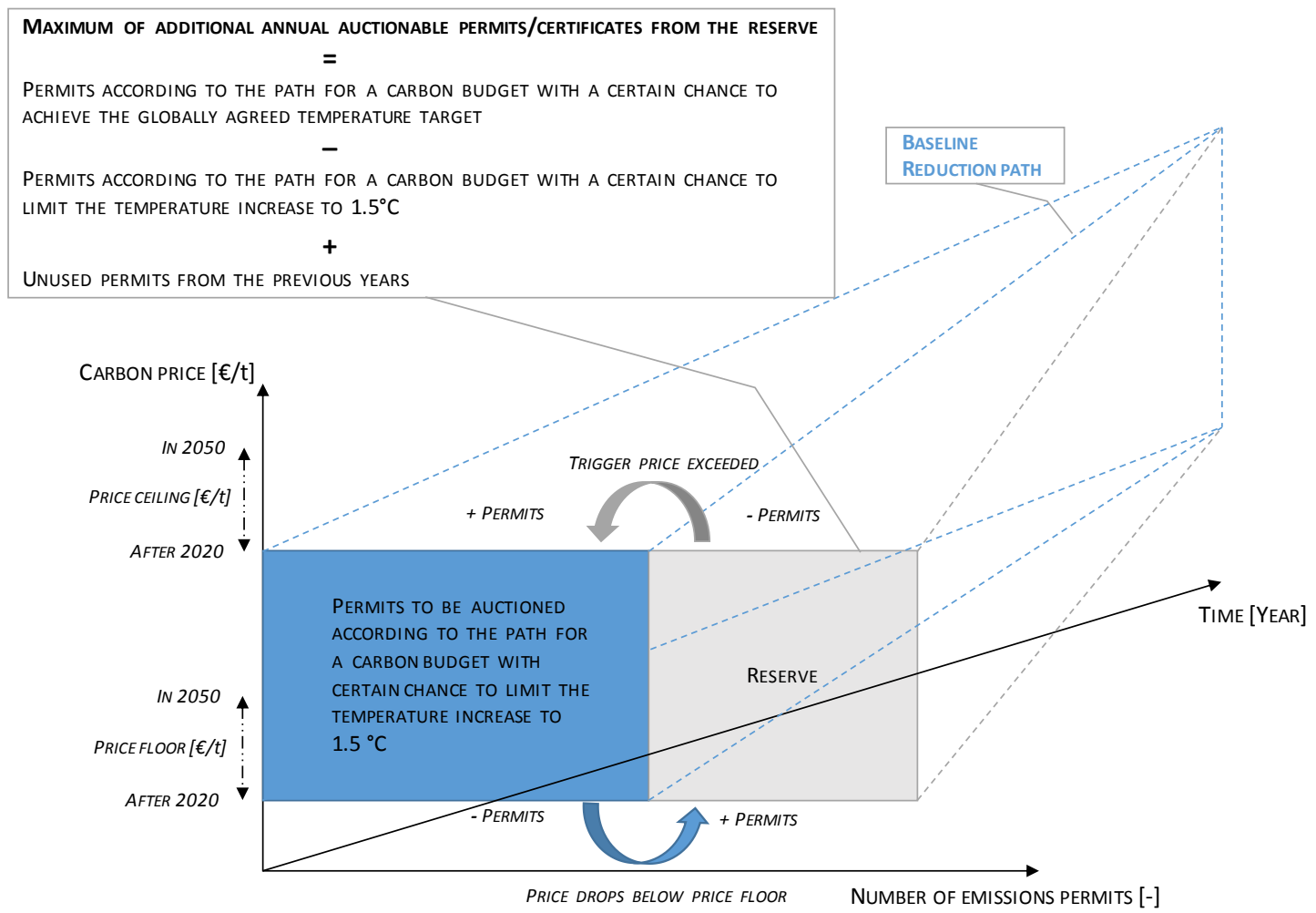

Figure 5. Proposal of a hybrid cap-and-trade system.

\subsection{Auctioning Emissions Permits}

In a global cap-and-trade system, emissions permits should not be issued to countries, according to certain emissions levels, as it was the case with the assigned amount units (AAU) between Annex I countries under the Kyoto Protocol [58]. Instead, a fixed quantity of certificates should be auctioned annually worldwide and traded between all actors. Socially acceptable uses of the revenues from the auctions are mentioned in Section 6.2. Free allocation by grandfathering has proved disadvantageous in the past, e.g., in the EU ETS, and should be abandoned. If the recipients of grandfathered permits pass on the opportunity cost of the permits to final consumers, windfall gains for the regulated entity are incurred. There are various advantages of an auction, compared to free allocation (cf. [56,59-61]).

\subsection{What Should the Money Be Used for That Is Collected within the Global Cap-and-Trade System}

Assuming that all polluters agree to take part in the proposed global cap-and-trade system, a significant amount of money would be collected annually. The order of magnitude involved is 1 to $4 \times 10^{12}$ USD or trillions of US dollars per year, assuming a starting value of $40 \mathrm{GtCO}_{2}$ and a carbon price, after auctioning, of $25-100 \mathrm{USD} / \mathrm{tCO}_{2}$ eq. An international authority would necessarily have to be implemented for the purpose of administering the money collected. The costs of climate change do not directly and exclusively affect the polluters but differ in time and space from the causes. Future generations are particularly affected. A direct return flow of the revenue from carbon pricing to households does not reflect this fact. Hence, a part of revenues from carbon trading should be used worldwide as a reserve to offset the effects of climate change. The fund could also be used in the following ways:

- Cushioning losses in value due to non-insurable damages that can be traced back to climate change;

- Promoting sustainable technologies (R\&D incentives and market ramp-up incentives) in order to enable a rapid global ramp-up of core technologies to implement emissions savings (cf. [62]). Such support corresponds to, for example, the Innovation Fund through the EU ETS [63]; 
- Enabling adaptation and investments, in developing countries that eventually lack the funding to implement even the cost-efficient solutions. This could be based on existing funds, like the Green Climate Fund (GCF) or Global Environmental Facility (GEF);

- Financing the net negative emissions, which may be necessary especially from 2050;

- Compensating for the eventual collapses of countries, industries and the financial system due to stranded assets caused by the fossil phase-out.

The proposed use of the fund could facilitate negotiation to enter a global agreement, in particular, with countries that are still strongly relying on fossil fuels or developing countries.

\subsection{Measurement and Control}

The emissions of GHG, without invalidating an emissions certificate, must be reviewed and sanctioned with significant penalties for non-compliance in order to ensure that the ETS functions properly and that the global reduction path is adhered to [22]. There is an administrative burden for this, which must be kept as low as possible by the appropriate design, e.g., a mixed system consisting of upstream and downstream ETS (with as few actors as possible). The mixed system design is derived and explained in Section 5.2. "Then, if the payment of the penalty is an alternative to compliance, the penalty is effectively a price ceiling in a hybrid scheme. In contrast, if the payment of the penalty does not amount to compliance-and the firm is still obliged to comply as soon as possible-then the scheme is not directly equivalent to a conventional hybrid scheme" [21]. In [43], an optimal trading policy is examined that ensures that regulated entities are always compliant by enforcing an explicit price ceiling and floor, as well as a penalty that vary directly with the permit price. This policy will always be more efficient than the one that uses imperfect compliance to provide a price ceiling. Accordingly, this design should be applied for a global cap-and-trade system.

\subsection{Extension of the $\mathrm{CO}_{2}$-Based Global Cap-and-Trade System to Non-CO $\mathrm{CO}_{2}$ GHG Emissions, AFOLU and Carbon Sinks}

The extent to which non- $\mathrm{CO}_{2}$ emissions can be integrated into a global ETS, such as nitrous oxide and methane, will need to be assessed. Among other things, it depends on whether it is possible to record emissions or correlate them with a GHG-causing input at a reasonable expense. Furthermore, the global warming potential (GWP) of short-lived climate forcers (SLCF), like methane, black carbon and fluorinated gases, should be considered in such a way that, compared to $\mathrm{CO}_{2}$, an equal impact is thereby covered $[8,64]$. For aviation, radiative forcing from NOx, contrail/ cirrus cloud formation and soot have to be considered [65]. These non- $\mathrm{CO}_{2}$ effects are strongly dependent on the location, altitude and time of emissions. Solutions must be found to convert these effects into equivalent $\mathrm{CO}_{2}$ emissions [66]. If non- $\mathrm{CO}_{2}$ emissions will be integrated in a global cap-and-trade system, then the reduction paths, shown in Figure 2, are not applicable. In this case, the paths have to be adjusted according to carbon dioxide equivalent budgets. If non- $\mathrm{CO}_{2}$ emissions cannot be integrated in a global cap-and-trade system, supplementary political instruments to reduce non- $\mathrm{CO}_{2}$ emissions have to be implemented.

Measures that generate carbon sinks, like afforestation, carbon capture and storage (CCS) or carbon capture and use (CCU), can also be integrated into a global upstream ETS by issuing emissions certificates for these measures (according to the $\mathrm{CO}_{2}$-removal in a respective time period). Furthermore, the reduction of natural $\mathrm{CO}_{2}$ sinks, e.g., through deforestation, can be considered by redeeming emissions certificates for such measures. If these measures are taken into account worldwide, the complex assessment of indirect land-use changes could be dispensed with. Moreover, the consideration of $\mathrm{CO}_{2}$ sinks would allow for the integration of biofuels and synthetic fuels into an upstream ETS. Otherwise, complex individual assessments of the emissions factors of these fuels are required.

In the long term, especially after 2050, no more emissions certificates would be auctioned, as net zero emissions must be achieved. However, emissions trading could be continued, if actors can 
continue to receive permits for implementing measures that generate $\mathrm{CO}_{2}$ sinks. This would allow for a cost-effective offset of anthropogenic GHG emissions, even after 2050. If negative emissions, e.g., from afforestation or BECCS, should also be taken into account, this implies that a justified assessment of these negative emissions is possible, according to the corresponding $\mathrm{CO}_{2}$ savings (cf. $[7,67,68]$ ).

\subsection{Substitution of Existing $\mathrm{CO}_{2}$-Related Governmental Intervention by the Global Cap-and-Trade System}

Once a global cap-and-trade system is implemented, all other complementary policies, e.g., from national governments, that aim to reduce emissions that are already covered under the cap should gradually be discontinued, such as Pigouvian taxes, subsidies and legal requirements. Continuing these measures would reduce the efficiency of the emissions trading system and lead to more costly reduction paths (cf. [22]). There is a self-serving incentive for countries not to introduce additional $\mathrm{CO}_{2}$ levies, since otherwise, a higher national price for $\mathrm{CO}_{2}$ or $\mathrm{GHG}$ emissions would put the domestic industry at a disadvantage. On the other hand, national subsidies for $\mathrm{CO}_{2}$-intensive products and energy sources must be examined and reduced. It should be mentioned here that emissions trading provides financial incentives for the gradual switch to a carbon-free international, but also national, industry. A national subsidy for $\mathrm{CO}_{2}$-intensive products and energy sources reduces this incentive, thus long-term transformation could be accompanied by higher national costs.

If the dissolution of existing $\mathrm{CO}_{2}$-related governmental intervention leads to a lower tax burden, this would reduce the final price increase due to global carbon prices for the end user and thus probably would increase acceptance. Nevertheless, a comprehensive tax reform could be necessary, avoiding hardship cases for low-income households due to the implementation of global carbon pricing.

In addition to a globally valid $\mathrm{CO}_{2}$ price, further policies are needed to advance the transformation to a carbon-free society, such as investment in public infrastructure and public transport or introducing and raising efficiency standards. Furthermore, innovative concepts are needed in future urban planning, agriculture and forestry. Moreover, it is essential to design an adapted market design for renewable electricity producers with low or no marginal costs. Political regulations in this respect can lead to a situation in which a certain emissions reduction can be implemented in the countries concerned with lower costs, unlike a situation in which these measures do not exist [69].

Compared to the current framework conditions for technologies, which are characterized by rapid changes and different $\mathrm{CO}_{2}$-prices, a global ETS with a uniform carbon price can guarantee long-term planning security. This is particularly necessary for technologies that require cost-intensive infrastructure development.

\subsection{Refutation of Objections to the Implementation of a Global Cap-and-Trade System}

In particular, restrictions are mentioned in publications regarding the functioning of a global ETS. It is argued that, for global emissions trading, long-term allocations of permits to countries are necessary, and these must be based on long-term estimates of future emissions. "When these estimates prove wrong, countries can find themselves with surprising windfall gains and losses, which have nothing to do with good climate policy" [24]. The breaking down of a global reduction target into national obligations is seen as a restriction for a global cap-and-trade system. However, the proposed design of a global ETS, in this paper, does not require the allocation of emissions permits to specific countries or the setting of emissions budgets for individual countries. Instead, a reduction path, with annually auctioned emissions certificates worldwide, is proposed (cf. Section 6.1). This provides less opportunity for rent-seeking. This is an issue that could otherwise (quantity approach with grandfathering) make taxes preferable to quantity control (cf. [35]).

Furthermore, the presumption that price-control is definitely preferable, which is based on the structure of the costs and damages in global warming (comparing the slopes), relating to Weitzman's rule (cf. $[35,42,70,71])$, is not confirmed by the latest scientific findings on climate change. The social cost of carbon is uncertain across a broad range and will always be disputed [16,72]. "The literature agrees that damages are a convex function of temperature, but the degree of the convexity is an open 
issue, inevitably subject to uncertainty; see, for instance, [73]" [74]. The SCC increases over time due to the effect of accumulation. This means that the bigger the stock size of greenhouse gases in the atmosphere, the greater the damage an additional unit will cause [75]. The triggering of tipping points could lead to a substantially increased amount of damage, which would occur abruptly and could not be reversed [28,76,77]. "Tipping points refer to critical thresholds in a system that, when exceeded, can lead to a significant change in the state of the system, often with an understanding that the change is irreversible" [78]. It is possible that climatic tipping elements, climatically sensitive social tipping elements, and climate economic shocks may be the largest contributors to the costs of climate change [79]. The risk of self-reinforcing feedbacks is explored, among other places, in [80]. The highly aggregated damage functions (deterministic fashion, sometimes giving climate catastrophes a probability distribution) in IAMs fail to consider that changes related to global warming are likely to be abrupt and unpredictable, and as such, they neglect the possibility of reaching tipping points [28,76]. "Multiple tipping points affect each other's probability of occurrence, potentially causing a domino effect" [81]. "Passing some tipping points increases the likelihood of other tipping points occurring, to such an extent that it abruptly increases the social cost of carbon" [28]. Multiple tipping points can lead to an increase of the social cost of carbon (SCC) by a factor of 2 to $8[28,81]$.

The informational requirements for calculating carbon budgets, which ensure an increase in temperature, with a certain probability in the temperature range of the Paris Agreement are much less than those needed for welfare maximization (cf. Section 5.1) [82]. To avoid tipping points, the carbon budget approach provides a decision-making framework that displaces benefit-cost analysis. If the carbon budget, based on current scientific findings, is complied with, tipping points and a certain temperature increase can be avoided, with a certain probability. The proposed global cap-and-trade system represents an instrument by which avoidance costs can be minimized, and, at the same time, the carbon budget can be guaranteed.

Another argument in favor of a global cap-and-trade system, compared to price control, is given in [83]. It is explained that the owners of carbon resources pre-empt future regulation by accelerating the production of fossil fuels while they can, because climate policy threatens to decrease future scarcity rents. This is called the green paradox, which means that expected future reduction in carbon consumption has the effect of accelerating climate change. An approach based, not on regulating the demand for fossil fuels, but rather on controlling the supply is proposed in [83]. A global cap-and-trade system would prevent international leakage and not fall victim to the green paradox, which supports the criterion for exclusion of a Pigouvian tax (cf. Section 5.1) [84].

In the past, there have been repeated criticisms of existing emissions trading systems, such as the EU ETS. The main disadvantages were grandfathering, a less ambitious reduction path, a lack of cross-sectoral validity, a missing price collar and additional complementary policies that reduce the efficiency of an ETS. These points have been taken up in this paper and an efficient design is proposed, based on past experiences and investigations.

\section{Discussion}

Current studies show, with detailed simulations, that compliance with the $1.5^{\circ} \mathrm{C}$ target is possible at a low cost using technologies already in existence [85]. The climate targets of the Paris Agreement could therefore be met using these technologies, if an efficient framework can be implemented. At this point, based on a literature review of the remaining carbon budgets and carbon pricing, a political instrument to this effect is put forward-a global emissions cap-and-trade system.

The High-Level Commission on carbon prices concludes that the explicit carbon-price level, consistent with achieving the Paris temperature target, is at least $40-80 \mathrm{USD} / \mathrm{tCO}_{2}$ by 2020 and $50-100$ $\mathrm{USD} / \mathrm{tCO}_{2}$ by 2030 [69]. In this paper, an alternative approach to their proposal is given, which has the advantage of ensuring that a carbon budget is met cost-effectively.

Finally, open issues concerning pathways toward a global emissions cap-and-trade system and further necessary research are discussed in the following. One of the main drawbacks of such a 
system is that it would have to be implemented on a global scale in order for it to have the advantages mentioned. Necessary research should hence involve the following research questions:

- What are the impediments to a global carbon price agreement, and how can they be overcome?

- How should a global ETS fund be structured and managed?

- Provided that the implementation of a global ETS is agreed upon, how can existing governmental interventions concerning climate protection be phased out? What would be an adequate roadmap for the discontinuation of national subsidies for fossil fuels?

The next best solution if a global agreement cannot be reached is to start an agreement for an international cap-and-trade system within a coalition of the willing (e.g., the European Union). Concerning this alternative, the following questions appear to be relevant for investigation:

- How much $\mathrm{CO}_{2}$ is imported/exported indirectly by product flows (cf. $\left.[49,86]\right)$ ?

- How could the imbalance between the coalition of the willing and the non-participants be compensated (e.g., border carbon adjustments)?

- How could carbon leakage and the green paradox be avoided as much as possible?

Author Contributions: Methodology, M.Z. and H.P.; validation, C.W.; formal analysis, C.W.; investigation, M.Z. and H.P; resources, M.Z.; writing-original draft preparation, M.Z. and H.P.

Funding: The APC was funded by the Bavarian Academic Forum (BayWiss).

Acknowledgments: The authors would like to thank the editors and reviewers for critically reviewing the manuscript.

Conflicts of Interest: The authors declare no conflict of interest.

\section{References}

1. United Nations Framework Convention on Climate Change (UNFCCC). The Paris Agreement. Available online: https://unfccc.int/resource/bigpicture/index.html\#content-the-paris-agreemen (accessed on 24 March 2019).

2. IPCC. Summary for Policymakers. In Global Warming of $1.5^{\circ} \mathrm{C}$ : An IPCC Special Report on the Impacts of Global Warming of $1.5^{\circ} \mathrm{C}$ above Pre-Industrial Levels and Related Global Greenhouse Gas Emission Pathways, in the Context of Strengthening the Global Response to the Threat of Climate Change, Sustainable Development, and Efforts to Eradicate Poverty; Masson-Delmotte, V., Zhai, P., Pörtner, H.-O., Roberts, D., Skea, J., Shukla, P.R., Pirani, A., Moufouma-Okia, W., Péan, C., Pidcock, R., et al., Eds.; World Meteorological Organization: Geneva, Switzerland, 2018.

3. IPCC. Climate Change 2013. The Physical Science Basis. Contribution of Working Group I to the Fifth Assessment Report of the Intergovernmental Panel on Climate Change; Stocker, F.T., Qin, D., Plattner, G.-K., Tignor, M., Allen, S.K., Boschung, J., Nauels, A., Xia, Y., Bex, V., Midgley, P.M., Eds.; Cambridge University Press: Cambridge, UK; New York, NY, USA, 2013.

4. IPCC. Climate Change 2014. Mitigation of Climate Change: Working Group III Contribution to the Fifth Assessment Report of the Intergovernmental Panel on Climate Change; Edenhofer, O., Pichs-Madruga, R., Sokona, Y., Farahani, E., Kadner, S., Seyboth, K., Adler, A., Baum, I., Brunner, S., Eickemeier, P., et al., Eds.; Cambridge University Press: Cambridge, UK; New York, NY, USA, 2014.

5. International Energy Agency (IEA). $\mathrm{CO}_{2}$ Emissions from Fuel Combustion. Higlights: OECD/IEA 2017. Available online: https://www.iea.org/publications/freepublications/publication/ CO2EmissionsfromFuelCombustionHighlights2017.pdf (accessed on 18 June 2019).

6. Allen, M.R.; de Coninck, H.; Dube, O.P.; Hoegh-Guldberg, O.; Jacob, D.; Jiang, K.; Revi, A.; Rogelj, J.; Roy, J.; Shindell, D.; et al. Technical Summary. In Global Warming of $1.5^{\circ} \mathrm{C}$ : An IPCC Special Report on the Impacts of Global Warming of $1.5^{\circ} \mathrm{C}$ above Pre-Industrial Levels and Related Global Greenhouse Gas Emission Pathways, in the Context of Strengthening the Global Response to the Threat of Climate Change, Sustainable Development, and Efforts to Eradicate Poverty; Masson-Delmotte, V., Zhai, P., Pörtner, H.-O., Roberts, D., Skea, J., Shukla, P.R., Pirani, A., Moufouma-Okia, W., Péan, C., Pidcock, R., et al., Eds.; World Meteorological Organization: Geneva, Switzerland, 2018. 
7. Rogelj, J.; Shindell, D.; Jiang, K.; Fifita, S.; Forster, P.; Ginzburg, V.; Handa, C.; Kheshgi, H.; Kobayashi, S.; Kriegler, E.; et al. Mitigation Pathways Compatible with $1.5^{\circ} \mathrm{C}$ in the Context of Sustainable Development. In Global Warming of $1.5^{\circ} \mathrm{C}$ : An IPCC Special Report on the Impacts of Global Warming of $1.5^{\circ} \mathrm{C}$ above Pre-Industrial Levels and Related Global Greenhouse Gas Emission Pathways, in the Context of Strengthening the Global Response to the Threat of Climate Change, Sustainable Development, and Efforts to Eradicate Poverty; Masson-Delmotte, V., Zhai, P., Pörtner, H.-O., Roberts, D., Skea, J., Shukla, P.R., Pirani, A., Moufouma-Okia, W., Péan, C., Pidcock, R., et al., Eds.; World Meteorological Organization: Geneva, Switzerland, 2018.

8. Allen, M.R.; Dube, O.P.; Solecki, W.; Aragón-Durand, F.; Cramer, W.; Humphreys, S.; Kainuma, M.; Kala, J.; Mahowald, N.; Mulugetta, Y.; et al. Framing and Context. In Global Warming of $1.5^{\circ} \mathrm{C}$ : An IPCC Special Report on the Impacts of Global Warming of $1.5^{\circ} \mathrm{C}$ above Pre-Industrial Levels and Related Global Greenhouse Gas Emission Pathways, in the Context of Strengthening the Global Response to the Threat of Climate Change, Sustainable Development, and Efforts to Eradicate Poverty; Masson-Delmotte, V., Zhai, P., Pörtner, H.-O., Roberts, D., Skea, J., Shukla, P.R., Pirani, A., Moufouma-Okia, W., Péan, C., Pidcock, R., et al., Eds.; World Meteorological Organization: Geneva, Switzerland, 2018.

9. Rockström, J.; Gaffney, O.; Rogelj, J.; Meinshausen, M.; Nakicenovic, N.; Schellnhuber, H.J. A roadmap for rapid decarbonization. Science 2017, 355, 1269-1271. [CrossRef] [PubMed]

10. Zapf, M.; Pengg, H.; Bütler, T.; Bach, C.; Weindl, C. Kosteneffiziente und nachhaltige Automobile. Bewertung der Klimabelastung und der Gesamtkosten-Heute und in Zukunft, 1st ed.; Springer Vieweg: Wiesbaden, Germany, 2019; ISBN 3658240598.

11. United Nations Environment Programme (UNEP). Ozone Secretariat. Ozone Depleting Substances (ODS) Consumption. Available online: https://ozone.unep.org/countries/data (accessed on 29 April 2019).

12. Hegglin, M.I.; Fahey, D.W.; McFarland, M.; Montzka, S.A.; Nash, E.R. Twenty Questions and Answers about the Ozone Layer; World Meteorological Organization: Geneva, Switzerland, 2015; ISBN 978-9966-076-02-1.

13. European Environment Agency (EEA). Sulphur Dioxide $\left(\mathrm{SO}_{2}\right)$ Emissions. Available online: https://www.eea. europa.eu/data-and-maps/indicators/eea-32-sulphur-dioxide-so2-emissions-1/assessment-3 (accessed on 16 April 2019).

14. Massetti, E.; Brown, M.A.; Lapsa, M.; Sharma, I.; Bradbury, J.; Cunliff, C.; Li, Y. Environmental Quality and the U.S. Environmental Quality and the U.S. Power Sector: Air Quality, Water Quality, Land Use and Environmental Justice. Available online: https://www.energy.gov/sites/prod/files/2017/01/f34/Environment\% 20Baseline\%20Vol.\%202--Environmental\%20Quality\%20and\%20the\%20U.S.\%20Power\%20Sector--Air\% 20Quality\%2C\%20Water\%20Quality\%2C\%20Land\%20Use\%2C\%20and\%20Environmental\%20Justice.pdf (accessed on 6 June 2019).

15. Grübler, A. The Rise and Fall of Infrastructures. Dynamics of Evolution and Technological Change in Transport; Physica-Verlag: Heidelberg, Germany, 1990; ISBN 978-0387913742.

16. Pezzey, J.C.V. Why the social cost of carbon will always be disputed. WIREs Clim. Chang. 2018, 10, e558. [CrossRef]

17. Bester, H. Theorie der Industrieökonomik, 7th ed.; Springer Gabler: Berlin/Heidelberg, Germany, 2017; ISBN 9783662481400 .

18. Sturm, B.; Vogt, C. Umweltökonomik. Eine anwendungsorientierte Einführung, 2nd ed.; Springer Gabler: Berlin, Germany, 2018; ISBN 9783662541265.

19. Deimer, K.; Pätzold, M.; Tolkmitt, V. Ressourcenallokation, Wettbewerb und Umweltökonomie; Springer Gabler: Berlin, Germany, 2017; ISBN 978-3-662-52765-8.

20. Schubert, R.; Ohndort, M.; Rohling, M. Umweltökonomie Kapitel III: Internalisierung Externer Effekte. Available online: http://webarchiv.ethz.ch/vwl/down/v-schubert/Umwelt/2012/Umwelt\%20MR\%20II.pdf (accessed on 22 March 2019).

21. Hepburn, C. Regulation by Prices, Quantities, or Both: A Review of Instrument Choice. Oxf. Rev. Econ. Policy 2006, 22, 226-247. [CrossRef]

22. Schmalensee, R.; Stavins, R.N. Lessons Learned from Three Decades of Experience with Cap and Trade. Rev. Environ. Econ. Policy 2017, 11, 59-79. [CrossRef]

23. Newell, R.G.; Stavins, R.N. Cost Heterogeneity and the Potential Savings from Market-Based Policies. J. Regul. Econ. 2003, 23, 43-59. [CrossRef]

24. Global Carbon Pricing. The Path to Climate Cooperation; Cramton, P.C.; MacKay, D.J.C.; Ockenfels, A.; Stoft, S. (Eds.) The MIT Press: Cambridge, MA, USA; London, UK, 2017; ISBN 9780262036269. 
25. Zaklan, A. Linking Cap-and-Trade Systems. Available online: https://www.diw.de/de/diw_01.c.593319.de/ presse/diw_roundup/linking_cap_and_trade_systems.html\#_ftn1 (accessed on 4 April 2019).

26. International Carbon Action Partnership. Emissions Trading Worldwide. Status Report 2018; ICAP: Berlin, Germany, 2018.

27. World Bank. Ecofys. State and Trends of Carbon Pricing 2018; License: Creative Commons Attribution CC BY 3.0 IGO; World Bank: Washington, DC, USA, 2018. [CrossRef]

28. Cai, Y.; Lenton, T.M.; Lontzek, T.S. Risk of multiple interacting tipping points should encourage rapid $\mathrm{CO}_{2}$ emission reduction. Nat. Clim. Chang. 2016, 6, 520-525. [CrossRef]

29. Nordhaus, W.D. Revisiting the social cost of carbon. Proc. Natl. Acad. Sci. USA 2017, 114, 1518-1523. [CrossRef] [PubMed]

30. Fleurbaey, M.; Ferranna, M.; Budolfson, M.; Dennig, F.; Mintz-Woo, K.; Socolow, R.; Spears, D.; Zuber, S. The Social Cost of Carbon: Valuing Inequality, Risk, and Population for Climate Policy. Monist 2019, 102, 84-109. [CrossRef]

31. FUND-Climate Framework for Uncertainty, Negotiation and Distribution. Available online: http://www. fund-model.org/home (accessed on 1 July 2019).

32. Nordhaus, W.D. The 'DICE' Model: Background and Structure of a Dynamic Integrated Climate-Economy Model of the Economics of Global Warming; Cowles Foundation for Research in Economics, Yale University: New Haven, CT, USA, 1992.

33. Hope, C.; Anderson, J.; Wenman, P. Policy analysis of the greenhouse effect. Energy Policy 1993, 21, $327-338$. [CrossRef]

34. Diaz, D.; Moore, F. Quantifying the economic risks of climate change. Nat. Clim. Chang. 2017, 7, 774-782. [CrossRef]

35. Nordhaus, W.D. To Tax or Not to Tax: Alternative Approaches to Slowing Global Warming. Rev. Environ. Econ. Policy 2007, 1, 26-44. [CrossRef]

36. Weitzman, M.L. Prices vs. Quantities. Rev. Econ. Stud. 1974, 41, 477-491. [CrossRef]

37. Stavins, R.N. Correlated Uncertainty and Policy Instrument Choice. J. Environ. Econ. Manag. 1996, 30, 218-232. [CrossRef]

38. Fell, H.; MacKenzie, I.A.; Pizer, W.A. Prices versus quantities versus bankable quantities. Resour. Energy Econ. 2012, 34, 607-623. [CrossRef]

39. Pommeret, A.; Schubert, K. Intertemporal Emission Permits Trading under Uncertainty and Irreversibility. Environ. Resour. Econ. 2018, 71, 73-97. [CrossRef]

40. Leiby, P.; Rubin, J. Intertemporal Permit Trading for the Control of Greenhouse Gas Emissions. Environ. Resour. Econ. 2001, 19, 229-256. [CrossRef]

41. Roberts, M.J.; Spence, M. Effluent charges and licenses under uncertainty. J. Public Econ. 1976, 5, $193-208$. [CrossRef]

42. Pizer, W.A. Combining price and quantity controls to mitigate global climate change. J. Public Econ. 2002, 85, 409-434. [CrossRef]

43. Stranlund, J.K.; Moffitt, L.J. Enforcement and price controls in emissions trading. J. Environ. Econ. Manag. 2014, 67, 20-38. [CrossRef]

44. Yu, J.; Mallory, M.L. An Optimal Hybrid Emission Control System in a Multiple Compliance Period Model. SSRN J. 2013. [CrossRef]

45. Perkis, D.F.; Cason, T.N.; Tyner, W.E. An Experimental Investigation of Hard and Soft Price Ceilings in Emissions Permit Markets. Environ. Resour. Econ. 2016, 63, 703-718. [CrossRef]

46. Fell, H.; Burtraw, D.; Morgenstern, R.D.; Palmer, K.L. Soft and hard price collars in a cap-and-trade system: A comparative analysis. J. Environ. Econ. Manag. 2012, 64, 183-198. [CrossRef]

47. Burtraw, D.; Palmer, K.; Kahn, D. A symmetric safety valve. Energy Policy 2010, 38, 4921-4932. [CrossRef]

48. Fell, H.; Morgenstern, R.D. Alternative Approaches to Cost Containment in a Cap-and-Trade System. Environ. Resour. Econ. 2010, 47, 275-297. [CrossRef]

49. Mehling, M.A.; van Asselt, H.; Das, K.; Droege, S. Beat protectionism and emissions at a stroke. Nature 2018, 559, 321-324. [CrossRef] [PubMed]

50. Edenhofer, O.; Flachsland, C.; Arlinghaus, J.; Haywood, L.; Kalkuhl, M.; Knopf, B.; Koch, N.; Kornek, U.; Pahle, M.; Pietzcker, R.; et al. Eckpunkte einer $\mathrm{CO}_{2}$-Preisreform für Deutschland: MCC Working Paper No. 
1/2018. Available online: https://www.mcc-berlin.net/fileadmin/data/B2.3_Publications/Working\%20Paper/ 2018_MCC_Working_Paper_1_CO2-Preisreform.pdf (accessed on 3 June 2019).

51. Stern, N. The Economics of Climate Change; Cambridge University Press: Cambridge, UK, 2007; ISBN 9780511817434.

52. Cramton, P.; Ockenfels, A.; Stoft, S.S. An International Carbon-Price Commitment Promotes Cooperation. EEEP 2015. [CrossRef]

53. Nordhaus, W. Climate Clubs: Overcoming Free-riding in International Climate Policy. Am. Econ. Rev. 2015, 105, 1339-1370. [CrossRef]

54. Die Wissenschaftlichen Dienste des Deutschen Bundestages (WD). Nationale bzw. EU-Weite Einbeziehung Weiterer Sektoren in das Europäische Emissionshandelssystem. Available online: https://www.bundestag.de/ resource/blob/554054/d82fa4578090812799515b50409f453e/wd-8-013-18-pdf-data.pdf (accessed on 19 March 2019).

55. Ekardt, F. Arbeitspapier zur Möglichen Totalrevision des Emissionshandels in Richtung Eines Upstream-ETS Entlang der Ziele Aus Art. 2 Abs. 1 Paris Abkommen. Available online: http://www.sustainability-justiceclimate.eu/files/texts/Arbeitspapier-Totalrevision-ETS.pdf (accessed on 19 March 2019).

56. Achtnicht, M.; von Graevenitz, K.; Koesler, S.; Löschel, A.; Schoeman, B.; Tovar, M. Including Road Transport in the EU-ETS-An Alternative for the Future? Available online: http://ftp.zew.de/pub/zew-docs/gutachten/ RoadTransport-EU-ETS_ZEW2015.pdf (accessed on 10 July 2019).

57. Narassimhan, E.; Gallagher, K.S.; Koester, S.; Alejo, J.R. Carbon pricing in practice: A review of existing emissions trading systems. Clim. Policy 2018, 18, 967-991. [CrossRef]

58. United Nations Framework Convention on Climate Change (UNFCCC). Emissions Trading. Available online: https://unfccc.int/process/the-kyoto-protocol/mechanisms/emissions-trading (accessed on 4 June 2019).

59. Brunner, S.; Flachsland, C.; Luderer, G.; Edenhofer, O. Emissions Trading Systems: An Overview: Discussion Paper. Available online: http://citeseerx.ist.psu.edu/viewdoc/download?doi=10.1.1.535.2125\&rep=rep1\& type $=$ pdf (accessed on 5 April 2019).

60. Cramton, P.; Kerr, S. Tradeable carbon permit auctions. Energy Policy 2002, 30, 333-345. [CrossRef]

61. Goeree, J.K.; Palmer, K.; Holt, C.A.; Shobe, W.; Burtraw, D. An Experimental Study of Auctions versus Grandfathering to Assign Pollution Permits. J. Eur. Econ. Assoc. 2010, 8, 514-525. [CrossRef]

62. De Coninck, H.; Revi, A.; Babiker, M.; Bertoldi, P.; Buckeridge, M.; Cartwright, A.; Dong, W.; Ford, J.; Fuss, S.; Hourcade, J.-C.; et al. Strengthening and Implementing the Global Response. In Global Warming of $1.5^{\circ} \mathrm{C}$ : An IPCC Special Report on the Impacts of Global Warming of $1.5^{\circ} \mathrm{C}$ above Pre-Industrial Levels and Related Global Greenhouse Gas Emission Pathways, in the Context of Strengthening the Global Response to the Threat of Climate Change, Sustainable Development, and Efforts to Eradicate Poverty; Masson-Delmotte, V., Zhai, P., Pörtner, H.-O., Roberts, D., Skea, J., Shukla, P.R., Pirani, A., Moufouma-Okia, W., Péan, C., Pidcock, R., et al., Eds.; World Meteorological Organization: Geneva, Switzerland, 2018.

63. European Commission. Innovation Fund. Available online: https://ec.europa.eu/clima/policies/innovationfund_de (accessed on 3 June 2019).

64. Allen, M.R.; Shine, K.P.; Fuglestvedt, J.S.; Millar, R.J.; Cain, M.; Frame, D.J.; Macey, A.H. A solution to the misrepresentations of $\mathrm{CO}_{2}$-equivalent emissions of short-lived climate pollutants under ambitious mitigation. Npj Clim. Atmos. Sci. 2018, 1, 16. [CrossRef]

65. Bock, L.; Burkhardt, U. Contrail cirrus radiative forcing for future air traffic. Atmos. Chem. Phys. 2019, 19, 8163-8174. [CrossRef]

66. Matthes, S.; Grewe, V.; Dahlmann, K.; Frömming, C.; Irvine, E.; Lim, L.; Linke, F.; Lührs, B.; Owen, B.; Shine, K.; et al. A Concept for Multi-Criteria Environmental Assessment of Aircraft Trajectories. Aerospace 2017, 4, 42. [CrossRef]

67. Jones, C.D.; Ciais, P.; Davis, S.J.; Friedlingstein, P.; Gasser, T.; Peters, G.P.; Rogelj, J.; van Vuuren, D.P.; Canadell, J.G.; Cowie, A.; et al. Simulating the Earth system response to negative emissions. Environ. Res. Lett. 2016, 11, 95012. [CrossRef]

68. Zickfeld, K.; Herrington, T. The time lag between a carbon dioxide emission and maximum warming increases with the size of the emission. Environ. Res. Lett. 2015, 10, 31001. [CrossRef]

69. High-Level Commission on Carbon Prices. Report of the High-Level Commission on Carbon Prices; Creative Commons Attribution CC BY 3.0 IGO; World Bank. License: Washington, DC, USA, 2017. 
70. Hoel, M.; Karp, L. Taxes and quotas for a stock pollutant with multiplicative uncertainty. J. Public Econ. 2001, 82, 91-114. [CrossRef]

71. Pizer, W.A. The optimal choice of climate change policy in the presence of uncertainty. Resour. Energy Econ. 1999, 21, 255-287. [CrossRef]

72. Ackerman, F.; Stanton, E.A. Climate Risks and Carbon Prices: Revising the Social Cost of Carbon. Econ. E-J. 2012, 6. [CrossRef]

73. Dietz, S.; Stern, N. Endogenous Growth, Convexity of Damage and Climate Risk: How Nordhaus' Framework Supports Deep Cuts in Carbon Emissions. Econ. J. 2015, 125, 574-620. [CrossRef]

74. Bretschger, L.; Pattakou, A. As Bad as it Gets: How Climate Damage Functions Affect Growth and the Social Cost of Carbon. Environ. Resour. Econ. 2019, 72, 5-26. [CrossRef]

75. Paul, I.; Howard, P.; Schwartz, J.A. The Social Cost of Greenhouse Gases and State Policy: A Frequently Asked Questions Guide. Available online: https://policyintegrity.org/files/publications/SCC_State_Guidance.pdf (accessed on 19 June 2019).

76. Belaia, M. Integrated Assessment of Climate Tipping Points. Ph.D. Thesis, Universität Hamburg, Hamburg, Germany, 2017.

77. Van der Ploeg, F. The safe carbon budget. Clim. Chang. 2018, 147, 47-59. [CrossRef]

78. Hoegh-Guldberg, O.; Jacob, D.; Taylor, M.; Bindi, M.; Brown, S.; Camilloni, I. Impacts of $1.5^{\circ} \mathrm{C}$ Global Warming on Natural and Human Systems. In Global Warming of $1.5^{\circ} \mathrm{C}$ : An IPCC Special Report on the Impacts of Global Warming of $1.5^{\circ} \mathrm{C}$ above Pre-Industrial Levels and Related Global Greenhouse Gas Emission Pathways, in the Context of Strengthening the Global Response to the Threat of Climate Change, Sustainable Development, and Efforts to Eradicate Poverty; Masson-Delmotte, V., Zhai, P., Pörtner, H.-O., Roberts, D., Skea, J., Shukla, P.R., Pirani, A., Moufouma-Okia, W., Péan, C., Pidcock, R., et al., Eds.; World Meteorological Organization: Geneva, Switzerland, 2018.

79. Kopp, R.E.; Shwom, R.L.; Wagner, G.; Yuan, J. Tipping elements and climate-economic shocks: Pathways toward integrated assessment. Earth's Future 2016, 4, 346-372. [CrossRef]

80. Steffen, W.; Rockström, J.; Richardson, K.; Lenton, T.M.; Folke, C.; Liverman, D.; Summerhayes, C.P.; Barnosky, A.D.; Cornell, S.E.; Crucifix, M.; et al. Trajectories of the Earth System in the Anthropocene. Proc. Natl. Acad. Sci. USA 2018, 115, 8252-8259. [CrossRef] [PubMed]

81. Lemoine, D.; Traeger, C.P. Economics of tipping the climate dominoes. Nat. Clim. Chang. 2016, 6, 514-519. [CrossRef]

82. Van der Ploeg, F. The Safe Carbon Budget. CESifo Working Paper Series No. 6620. Available online: https://ssrn.com/abstract=3036321 (accessed on 18 June 2019).

83. Sinn, H.-W. The Green Paradox. A Supply-Side Approach to Global Warming; MIT Press: Cambridge, MA, USA, 2012; ISBN 9780262016680.

84. Sinn, H.-W. Introductory Comment-The Green Paradox: A Supply-Side View of the Climate Problem. Rev. Environ. Econ. Policy 2015, 9, 239-245. [CrossRef]

85. Ram, M.; Bogdanov, D.; Aghahosseini, A.; Gulagi, A.; Oyewo, A.S.; Child, M.; Caldera, U.; Sadovskaia, K.; Farfan, J.; Barbosa, L.; et al. Global Energy System Based on 100\% Renewable Energy-Power, Heat, Transport and Desalination Sectors; Study by Lappeenranta University of Technology and Energy Watch Group: Lappeenranta, Finland; Berlin, Germany, 2019; ISBN 978-952-335-339-8.

86. Davis, S.J.; Caldeira, K. Consumption-based accounting of $\mathrm{CO}_{2}$ emissions. Proc. Natl. Acad. Sci. USA 2010, 107, 5687-5692. [CrossRef] [PubMed]

(C) 2019 by the authors. Licensee MDPI, Basel, Switzerland. This article is an open access article distributed under the terms and conditions of the Creative Commons Attribution (CC BY) license (http://creativecommons.org/licenses/by/4.0/). 